\title{
STUDI EVALUATIF PERAN HAKIM AD HOC dALAM PENYELESAIAN PERSELISIHAN HUBUNGAN INdUSTRIAL dI PENGAdILAN HUBUNGAN INdUSTRIAL YOGYAKARTA
}

\author{
Tata Wijayanta dan Ari Hernawan \\ Fakultas Hukum Universitas Gadjah Mada Yogyakarta \\ e-mail : tata_wijayanta@yahoo.com, ari2-gma@yahoo.com
}

\begin{abstract}
The research aim to evaluate the role of ad hoc judges in the settlement of industrial relation disputes, as well as to explore further what are the obstacles which may occur in the course of performing their duties. The research is a normative-empiric legal research. The data research comes from secondary data derived from literature studies and primary data from field researches. The data analyzed by qualitatively. The results of this research will show that ad hoc judges are appointed by the Supreme court and assigned to cases by the President of the court of Industrial Relations. Since its establishment, there has only been two appointments of ad hoc judges (one from the enterpreneur and the other from the labor union), and the court has tried and decided upon 104 cases (2006-2011). The most paramount obstacle turns out to be the lack of knowledge of the ad hoc judges in civil procedural laws while trying and deciding cases before them.
\end{abstract}

Keywords: court of Industrial Relations, Ad hoc Judge

\begin{abstract}
Abstrak
Penelitian ini bertujuan untuk mengevaluasi peran hakim ad hoc dan untuk mengkaji hambatan-hambatan yang dialami hakim ad hoc dalam penyelesaian perselisihan hubungan industrial di Pengadilan Hubungan Industrial (PHI). Penelitian ini merupakan penelitian hukum empiris bersumber pada data sekunder dan data primer melalui penelitian kepustakaan dan penelitian lapangan Data dianalisis secara kualitatif. Hasil penelitian menunjukan bahwa hakim ad hoc diangkat oleh Mahkamah Agung dan ditunjuk dalam suatu perkara oleh Ketua PHI. Sejak didirikan PHI yogyakarta hanya terdapat dua hakim ad hoc yang masing-masing merupakan perwakilan dari pengusaha dan pekerja. Sebanyak 104 perkara diperiksa dan diputus oleh PHI yogyakarta antara 2006-2011. Hambatan utama yaitu kurangnya pengetahuan dan pemahaman hakim ad hoc tentang hukum acara perdata yang menghambat ketika para hakim ad hoc ini harus memeriksa dan memutus perkara.
\end{abstract}

Kata kunci: Pengadilan hubungan industrial, Hakim ad hoc

\section{A. Pendahuluan}

Salah satu hal penting dalam penyelesaian perselisihan hubungan industrial setelah diundangkannya Undang-Undang Republik Indonesia Nomor 2 Tahun 2004 tentang Penyelesaian Perselisihan Hubungan Industrial (Lembaran Negara Republik Indonesia (LNRI) Tahun 2004 Nomor 6, Tambahan Lembaran Negara Republik Indonesia (TLNRI) Nomor 4356). adalah dibentuknya pengadilan hubungan industrial. Pengadilan ini didirikan sebagai pelaksanaan dari Pasal 126 Undang-undang Republik Indonesia Nomor 2 Tahun 2004.

Undang-Undang Republik Indonesia Nomor 2 Tahun 2004 tentang Penyelesaian Perselisihan

Yustisia Vol. 3 No. 1 Januari - April 2014
Hubungan Industrial menyebutkan bahwa untuk pertama kali dengan undang-undang ini dibentuk pengadilan hubungan industrial pada setiap pengadilan negeri kabupaten/kota yang berada di setiap ibukota propinsi yang daerah hukumnya meliputi propinsi yang bersangkutan, namun demikian di kabupaten/kota terutama yang padat industri, dengan keputusan presiden harus segera dibentuk pengadilan hubungan industrial pada pengadilan negeri setempat (Ari Hernawan, 2011: 363-364).

Berdasarkan Pasal 60 Undang-Undang Republik Indonesia Nomor 2 Tahun 2004 tentang Penyelesaian Perselisihan Hubungan Industrial disebutkan bahwa susunan majelis hakim pada pengadilan hubungan industrial terdiri dari

Studi evaluatif Peran Hakim Ad hoc dalam ... 
hakim karir dan hakim ad hoc. Dalam praktek pemeriksaan perkara di pengadilan hubungan industrial, komposisi majelis hakim dalam pemeriksaan perkara hubungan industrial terdiri dari seorang hakim karir, dan dua orang hakim ad hoc. Masing-masing hakim ad hoc dicalonkan dari pihak asosiasi pengusaha dan serikat pekerja (Ari Hernawan, 2011: 381).

Komposisi susunan majelis hakim seperti ini sangat berlainan dengan susunan majelis hakim pada peradilan umum (pengadilan negeri) (Sudikno Mertokusumo, 2009: 18) ataupun pada pengadilan khusus lainnya yang dibentuk dalam lingkungan peradilan umum. Sebagai contoh dalam hal ini adalah susunan majelis hakim pada pengadilan niaga yang terdiri dari dua hakim karir dan satu hakim ad hoc (Tata Wijayanta, 2007: 136). Berdasarkan hasil penelitian menunjukan bahwa keberadaan hakim ad hoc di pengadilan khusus ini ternyata tidak efektif (Tata Wijayanta, 2004: 38). Sebagai contoh misalnya pada waktu dibentuknya pengadilan niaga telah dilantik 13 hakim ad hoc, namun demikian dari ketiga belas hakim ad hoc yang dilantik tersebut yang berperan aktif terlibat dalam pemeriksaan perkara hanya satu hakim (Tata Wijayanta, 2008: 110). Ketidakterlibatan hakim ad hoc tersebut dalam pemeriksaan perkara diantaranya dikarenakan kurangpahamnya para hakim ad hoc yang dilantik tersebut tentang hukum acara di pengadilan (Tata Wijayanta, 2008: 110).

Berdasarkan hal tersebut, implementasi hakim ad hoc dalam penyelesaian perselisihan hubungan industrial di pengadilan hubungan industrial dalam praktek penting untuk memperoleh perhatian. Atas dasar alasan tersebut, penelitian tentang studi evaluatif peran hakim ad hoc dalam penyelesaian perselisihan hubungan industrial di $\mathrm{PHI}$ ini dilakukan

Berdasarkan Iuraian tersebut maka permasalahan yang diteliti dalam penelitian ini adalah bagaimana peran hakim ad hoc dalam penyelesaian perselisihan hubungan industrial di Pengadilan Hubungan Industrial yogyakarta dan apakah hambatan-hambatan yang dihadapi oleh hakim ad hoc Pengadilan Hubungan Industrial yogyakarta dalam menjalankan perannya selama ini dalam praktek?

\section{B. Metode Penelitian}

Penelitian ini merupakan penelitian hukum empiris. Penelitian hukum empiris adalah penelitian hukum yang menggunakan data primer melalui penelitian lapangan (Ronny Hanitijo Soemitro, 1994: 52). Penelitian lapangan dilakukan di yogyakarta dengan lokasi penelitian di Kantor Pengadilan Hubungan Industrial yogyakarta, Kantor Asosiasi Pengusaha Indonesia (Apindo) dan Kantor Serikat Pekerja, dengan sampel 1 (satu) orang Ketua dan 1 (satu) orang Hakim Pengadilan Hubungan Industrial, 1 (satu) orang Panitera Perdata Pengadilan Hubungan Industrial, 1 (satu) orang Hakim Ad hoc Pengadilan Hubungan Industrial dari unsur pengusaha, 1 (satu) orang Hakim Ad hoc Pengadilan Hubungan Industrial dari unsur pekerja, pekerja dan pengusaha yang pernah terlibat dalam penyelesaian perselisihan hubungan industrial di Pengadilan Hubungan Industrial yogyakarta masing-masing 1 (satu) orang atau advokat yang mewakilinya. Data penelitian kepustakaan dikumpulkan dengan metode dokumentasi yaitu dengan cara merujuk kepada bahan-bahan yang didokumentasikan (Ranjit Kumar, 1999: 104) dengan mengunakan alat studi dokumen (Suharsimi Arikunto, 1993: 93), sedangkan data penelitian lapangan berasal dari wawancara dengan menggunakan alat pengumpulan data yaitu pedoman wawancara (Maria SW. Sumarjono, 1989: 50). Data primer dan sekunder yang diperoleh dari penelitian kepustakaan dan lapangan dianalis dengan menggunakan metode kualitatif. Analisis kualitatif ini dilakukan dengan memperhatikan fakta yang ada di lapangan dan digabungkan dengan data sekunder yang diperoleh dari bahan kepustakaan. Hasil analisis tersebut akan dipaparkan secara deskriptif sehingga diperoleh uraian hasil penelitian yang bersifat deskriptif-kualitatif.

\section{Hasil Penelitian dan Pembahasan}

1. Hakim Ad Hoc dalam Penyelesaian Perselisihan Hubungan Industrial di Pengadilan Hubungan Industrial Yogyakarta

Pengadilan Hubungan Industrial yogyakarta dibentuk berdasarkan amanat Undang-Undang Republik Indonesia Nomor 2 Tahun 2004 tentang Penyelesaian Perselisihan Hubungan Industrial. Seharusnya pengadilan ini dibentuk bersamaan dengan diundangkannya undang-undang ini, namun demikian, karena alasan belum siap maka pelaksanaan pembentukan Pengadilan Hubungan Indutrial baru dapat direalisasikan dan beroperasi pada tahun 2006. Oleh karena itu, sejak didirikannya sampai dengan sekarang ini Pengadilan Hubungan Industrial i yogyakarta baru berumur kurang lebih 6 (enam) tahun dan gedung Pengadilan Hubungan Industrial yogyakarta merupakan 
gedung bekas P4D hingga sekarang ini (Rani Murni Indyastuti, 2012: Wawancara 18 Mei).

Pengadilan Hubungan Industrial yogyakarta didirikan dalam lingkungan Pengadilan Negeri yogyakarta. Pengadilan Hubungan Industrial yogyakarta (Rani Murni Indyastuti, 2012: Wawancara 18 Mei). Pengadilan ini merupakan pengadilan khusus dan mempunyai kewenangan memeriksa dan memutus perkara hubungan industrial.

Pengadilan Hubungan Industrial merupakan pengadilan khusus yang berada pada lingkungan peradilan umum (Rani Murni Indyastuti, 2012: Wawancara 18 Mei). Meskipun Pengadilan Hubungan Industrial yogyakarta dibentuk dalam lingkungan Pengadilan Negeri yogyakarta, namun yuridiksi dan kmpetensi pengadilan ini berbeda dengan yuridiksi dan kompetensi Pengadilan Negeri yogyakarta.

yuridiksi Pengadilan Negeri yogyakarta hanya meliputi wilayah kota yogyakarta, sedangkan yurisdiksi dari Pengadilan Hubungan Industrial yogyakarta adalah wilayah Daerah Istimewa yogyakarta. Meskipun Pengadilan Hubungan Industrial sekarang ini baru ada satu di Provinsi Daerah Istimewa yogyakarta dan meskipun hal ini tidak sesuai dengan ketentuan peraturan perundang-undangan, namun pertimbangan hanya dibentuknya satu pengadilan hubungan industrial tersebut yaitu bahwa yogyakarta bukan merupakan daerah padat industri (Rani Murni Indyastuti, 2012: Wawancara 24 April) dan faktanya setelah enam tahun berdirinya Pengadilan Hubungan Industrial di yogyakarta tidak banyak perkara hubungan indistrial yang ditangani sampai ke tahap pemeriksaan perkara di pengadilan (Rani Murni Indyastuti, 2012: Wawancara 24 April).

Berdasarkan Pasal 50 UU RI Nomor 2 Tahun 1986 tentang Peradilan Umum (LNRI 1987 Nomor 20, TLNRI Nomor 3327), kompetensi Pengadilan Negeri yogyakarta yaitu memeriksa dan memutus perkara perdata dan pidana dalam tingkat pertama. Menurut Pasal 2 ayat (1) Staatsblad 1847 Nomor 23 tentang Reglement op de Rechterlijke Organisatie in het Beleid der Justitie Indonesie (RO). yang dimaksudkan dengan perkara perdata meliputi semua peselisihan tentang hak milik atau hak-hak yang timbul karenannya, utang-piutang atau hak-hak perdata yang lain, kecuali sekiranya undang-undang memberikan kewenangan pengadilan lain untuk memeriksa dan memutusnya. Pengadilan negeri ini disebut juga sebagai pengadilan tingkat pertama (original Jurisdiction) (Sudikno Mertokusumo, 2009: 15), sedang kompetensi Pengadilan Hubungan Industrial yogyakarta yaitu memeriksa dan memutus : (1) di tingkat pertama mengenai perselisihan hak, (2) ditingkat pertama dan terakhir mengenai perselisihan kepentingan, (3) ditingkat pertama mengenai perselisihan pemutusan hubungan kerja, dan (4) ditingkat pertama dan terakhir mengenai perselisihan antar serikat pekerja /serikat buruh dalam satu perusahaan.

Perselisihan Hubungan Industrial adalah perbedaan pendapat yang mengakibatkan pertentangan antara pengusaha atau gabungan pengusaha dengan pekerja/ buruh atau serikat pekerja/serikat buruh karena adanya perselisihan mengenai hak, perselisihan kepentingan, perselisihan pemutusan hubungan kerja dan perselisihan antar serikat pekerja/serikat buruh dalam satu perusahaan (Ari Hernawan, 2011: 85). Perselisihan hak adalah perselisihan yang timbul karena tidak dipenuhinya hak, akibat adanya perbedaan pelaksanaan atau penafsiran terhadap ketentuan peraturan perundang-undangan, perjanjian kerja, peraturan perusahaan, atau perjanjian kerja bersama. Perselisihan kepentingan adalah perselisihan yang timbul dalam hubungan kerja karena tidak adanya kesesuaian pendapat mengenai pembuatan, dan atau perubahan syarat-syarat kerja yang ditetapkan dalam perjanjian kerja, atau peraturan perusahaan, atau perjanjian kerja bersama. Perselisihan pemutusan hubungan kerja adalah perselisihan yang timbul karena tidak adanya kesesuaian pendapat mengenai pengakhiran hubungan kerja yang dilakukan oleh salah satu pihak. Perselisihan antar serikat pekerja/serikat buruh adalah perselisihan antara serikat pekerja/serikat buruh dengan serikat pekerja/serikat buruh lain hanya dalam satu perusahaan, karena tidak adanya persesuaian paham mengenai keanggotaan, pelaksanaan hak, dan kewajiban keserikatpekerjaan.

Susunan dan struktur organisasi pengadilan hubungan industrial yogyakarta terdiri dari Hakim, Hakim Ad-hoc, Panitera Muda; dan Panitera Pengganti. Hakim-hakim pengadilan hubungan industrial yogyakarta diketuai oleh ketua dan wakil ketua. Panitera 
dan jurusita diketuai oleh panitera yang bertanggungjawab langsung kepada ketua/ wakil ketua pengadilan hubungan industrial.

Di pengadilan hubungan industrial dapat diangkat hakim ad hoc, namun hakim ini tidak termasuk dalam struktur organisasi pengadilan niaga. Pengangkatan hakim ad hoc bersifat sementara, terbatas untuk perkara tertentu. Hal ini bermakna tugas memeriksa dan memutus perkara akan selesai setelah dijatuhkan putusan.

Salah satu alasan utama dimasukkannya hakim ad hoc dalam pemeriksaan perkara di pengadilan hubungan industrial adalah untuk membantu para hakim karir dalam menganalisis berbagai perkara hubungan industrial yang dihadapi. Oleh karenanya atas dasar itu diperlukan hakim yang ahli yang disebut juga hakim ad hoc. Alasan lain atas keberadaan hakim ad hoc ini karena para hakim karir banyak yang tidak memahami hukum ketenagakerjaan dalam arti luas. Berdasarkan hal tersebut peran hakim ad hoc sangat diharapkan terlebih jika hakim ad hoc tersebut berasal dari kalangan professional yang memahami praktek-praktek di lapangan.

Hakim ad hoc untuk perkara-perkara di pengadilan dibutuhkan untuk memberikan keseimbangan terutama jika ada masalahmasalah yang kompleks seperti yang menyangkut hukum perdata internasional, cyber law. Berbeda dengan hakim ad hoc di pengadilan khusus lainnya, seperti pengadilan niaga dan pengadilan tipikor, hakim ad hoc di pengadilan hubungan industrial berasal dari wakil pengusaha dan wakil serikat pekerja. Oleh karena itu, komposisi majelis hakim pengadilan hubungan insdustrial terdiri dari satu orang hakim karir sebagai ketua majelis dan dua orang hakim ad hoc. Satu hakim ad hoc merupakan wakil dari pengusaha dan yang lainnya adalah wakil dari serikat pekerja. Komposisi tersebut adalah cermin dari upaya mempertahankan model tripartit dalam sistem pengadilan hubungan industrial sebagimana terdapat dalam Panitia penyelesaian perselisihan Perburuhan Daerah/Pusat yang digantikannya.

Satu hal yang terkait dengan kedudukan hakim ad hoc adalah asas imparsialitas dimana hakim tidak boleh memihak salah satu pihak yang berperkara. Dengan kata lain hakim harus netral dan wajib mendengarkan keterangan kedua belah pihak yang berselisih secara jujur dan adil. Hal ini dapat menjadi dilema karena di satu sisi harus berpihak pada yang diwakilinya dan di saat yang sama juga harus bersikap imparsial.

Jumlah Hakim Karir di Pengadilan Hubungan Industrial yogyakarta untuk saat ini berjumlah tujuh orang. Di Pengadilan Hubungan Industrial yogyakarta jumlah hakim karir lebih banyak jika dibandingkan dengan hakim ad-hoc Jumlah hakim adhoc yang merupakan perwakilan dari serikat pengusaha berjumlah dua orang. Jumlah hakim ad hoc dari perwakilan serikat pekerja berjumlah dua orang. Kesemuanya itu dibantu oleh satu orang panitera muda, dua orang panitera pengganti dan dua orang

Undang-undang Republik Indonesia Nomor 2 Tahun 2004 tentang Penyelesaian Perselisihan Hubungan Industrial telah membagi perselisihan hubungan industrial menjadi empat macam yaitu perselisihan hak, perselisihan kepentingan, perselisihan pemutusan hubungan kerja dan perselisihan antar serikat pekerja hanya dalam satu perusahaan. Konflik atau perselisihan hubungan industrial dapat disebabkan oleh beberapa faktor yaitu konflik data, konflik kepentingan, konflik hubungan, konflik struktur dan konflik nilai (Lalu Husni, 2005: 3-5).

Berdasarkan data di Pengadilan Hubungan Industrial yogyakarta, sebagian besar perkara yang didaftar dan diputus oleh pengadilan ini adalah perkara pemutusan hubungan kerja dan perkara perselisihan hak, sedangkan untuk perselisihan antar serikat pekerja belum pernah ditangani oleh Pengadilan Hubungan Industrial yogyakarta. Meskipun perselisihan antar serikat pekerja belum pernah terjadi, namun wakil dari serikat pekerja sering beracara di Pengadilan Hubungan Industrial yogyakarta untuk kepentingan anggotanya yang terlibat kasus Pemutusan Hubungan Kerja atau Perselisihan Hak.

Penyelesaian perselisihan hubungan industrial melalui pengadilan hubungan Industrial baru dapat dilakukan jika sudah ditempuh jalur non litigasi (bipartit dan tripartit) tetapi penyelesaiannya gagal di tahapan tersebut. Hal ini berarti bahwa para pihak yang berselisih tidak dapat langsung mengajukan gugatan ke pengadilan hubungan industrial tanpa melalui mekanisme bipartit dan tripartit terlebih dahulu.

Berdasarkan data statistik jumlah perkara yang didaftar dan diputus di Pengadilan Hubungan Industrial yogyakarta menunjukkan 
bahwa dari tahun 2006 sampai dengan 2011 jumlah perkara yang diputus oleh Pengadilan Hubungan Industrial yogyakarta menunjukan jumlah yang tidak terlalu banyak. Adapun rinciannya adalah sebagai berikut: pada tahun 2006 diperiksa sebanyak 10 perkara. Tahun 2007 jumlah perkara yang ditangani adalah sebanyak 15 perkara. Tahun 2008 jumlah perkara yang ditangani adalah sebanyak 10 perkara. Tahun 2009 jumlah perkara yang ditangani adalah sebanyak 20 perkara. Tahun 2010 jumlah perkara yang ditangani adalah sebanyak 17 perkara dan pada tahun 2011 jumlah perkara yang ditangani adalah sebanyak 12 perkara (Tabel 1 dan Diagram 1).

Tabel. 1Jumlah Perkara yang Didaftar Dan Diputus PHI yogyakarta (2006-2011)

\begin{tabular}{|c|c|c|}
\hline No. & Tahun & Jumlah Perkara \\
\hline 1 & 2006 & 10 \\
\hline 2 & 2007 & 15 \\
\hline 3 & 2008 & 10 \\
\hline 4 & 2009 & 20 \\
\hline 5 & 2010 & 17 \\
\hline 6 & 2011 & 12 \\
\hline \multicolumn{2}{|r|}{ Jumlah } & 104 \\
\hline
\end{tabular}

Sumber: PhI Yogyakarta, 2012

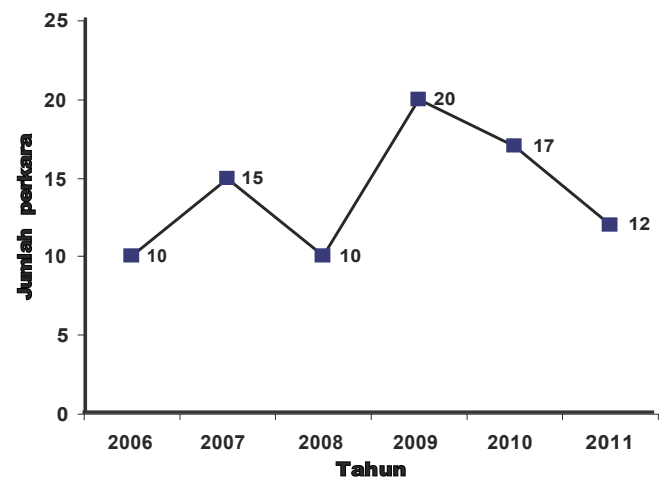

diagram. 1Jumlah Perkara Yang didaftar dan diputus PHI Yogyakarta (2006-2011)Sumber: PHI Yogyakarta, 2012

Berdasarkan data di atas, jumlah perkara yang didaftar dan diputus oleh Pengadilan Hubungan Industrial yogyakarta jumlahnya relatif sedikit. Hal ini berkorelasi dengan jumlah perusahaan dan tenaga kerja di yogyakarta relatif sedikit. Data dari Badan Pusat Statistik Provinsi Daerah Istimewa yogyakarta ditemukan bahwa jumlah perusahaan industri besar dan sedang antara antara tahun 2009-2011 hanya sebanyak 1.180 perusahaan (Tabel 2).
Faktor lain yang mebuat jumlah perkara yang didaftar dan diputus oleh Pengadilan hubungan Industrial yogyakarta sedikit adalah dapat diciptakan hubungan yang baik diantara pengusaha dan pekerja yang ada oleh dinas terkait di yogyakarta. Demikian juga penyelesaian perkara melalui proses bipartit dan tripartit sudah berjalan dengan baik di wilayah yogyakarta, sehingga tidak harus diselesaikan melalui pengadilan.

Tabel. 2

Jumlah Perusahaan Industri Besar dan

Sedang Menurut Golongan Pokok Industri Di Provinsi Daerah Istimewa yogyakarta (20092011).

\begin{tabular}{|c|c|c|c|c|}
\hline No. & $\begin{array}{l}\text { Kode Golongan Pokok } \\
\text { Industri(1) }\end{array}$ & \begin{tabular}{|c|}
2009 \\
$(2)$
\end{tabular} & $\begin{array}{c}2010 \\
(3)\end{array}$ & $\begin{array}{c}2011 \\
(4)\end{array}$ \\
\hline 1. & Makanan dan minuman & 44 & 44 & 36 \\
\hline 2. & Tembakau & 5 & 6 & 5 \\
\hline 3. & Tekstil & 35 & 36 & 30 \\
\hline 4. & Pakaian jadi & 28 & 30 & 27 \\
\hline 5. & Kulit dan barang kulit & 31 & 28 & 20 \\
\hline 6. & $\begin{array}{l}\text { Kayu dan barang dari kayu } \\
\text { (tidak termasuk furniture) }\end{array}$ & 45 & 51 & 46 \\
\hline 7. & $\begin{array}{l}\text { Penerbitan, percetakan dan } \\
\text { reproduksi media rekaman }\end{array}$ & 24 & 24 & 23 \\
\hline 8. & $\begin{array}{l}\text { Kimia dan barang-barang } \\
\text { dari bahan kimia }\end{array}$ & 11 & 10 & 6 \\
\hline 9. & $\begin{array}{l}\text { Karet dan barang-barang } \\
\text { dari karet }\end{array}$ & 10 & 12 & 9 \\
\hline 10. & Barang galian bukan logam & 50 & 51 & 49 \\
\hline 11. & $\begin{array}{l}\text { B arang-barang dari } \\
\text { logam kecuali mesin dan } \\
\text { peralatannya }\end{array}$ & 8 & 8 & 7 \\
\hline 12. & Mesin dan perlengkapannya & 8 & 7 & 3 \\
\hline 13. & $\begin{array}{l}\text { Mesin listrik lainnya dan } \\
\text { perlengkapannya }\end{array}$ & 1 & 1 & 6 \\
\hline 14. & $\begin{array}{l}\text { Alat angkutan selain ken- } \\
\text { daraan bermotor roda empat } \\
\text { atau lebih }\end{array}$ & 3 & 2 & 3 \\
\hline 15. & $\begin{array}{l}\text { Furniture dan industri pengo- } \\
\text { lahan lainnya }\end{array}$ & 99 & 101 & 97 \\
\hline \multicolumn{2}{|c|}{ Jumlah } & 402 & 411 & 367 \\
\hline
\end{tabular}

2. Hambatan-hambatan yang Dihadapi Oleh Hakim Ad hoc Pengadilan Hubungan Industrial yogyakarta Dalam Menjalankan Perannya Selama ini Dalam Praktek

Dibukanya peluang pengusaha dan buruh ke pengadilan hubungan industrial mengukuhkan keyakinan yang terdapat dalam ideologi demokrasi liberal akan adanya nilai-nilai yang melampaui dan berada di atas kelompok yang berkonflik, dalam hal ini pengusaha dan buruh. Pengadian Hubungan Industrial pun dipandang sebagai pengawal kepentingan komunitas secara keseluruhan. 
Pada saat sekarang ini jumlah Hakim Ad-hoc di Pengadilan Hubungan Industrial yogyakarta ada dua orang. satu orang hakim ad hoc merupakan perwakilan dari pengusaha dan satu orang yang lain merupakan perwakilan dari pekerja.

Hakim ad hoc diangkat oleh Mahkamah Agung berdasarkan usulan asosiasi pekerja dan pengusaha. Hanya saja dalam praktek ditemukan fakta bahwa serikat pekerja yang dapat mengusulkan hakim ad-hoc adalah serikat pekerja yang memiliki mayoritas anggota dalam suatu daerah. Sebagai contohnya di yogyakarta adalah Serikat Pekerja Seluruh Indonesia (SPSI) dan Serikat Pekerja Nasional (SPN). Sementara itu, hakim ad hoc perwakilan pengusaha diusulkan oleh Asosiasi Pengusaha Indonesia (Apindo).

Pada saat pertama kali Pengadilan Hubungan Industrial yogyakarta dibentuk terdapat satu hakim ad-hoc yang merupakan satu-satunya perwakilan dari serikat buruh yang ada di yogyakarta yang tergabung dalam Serikat Pekerja Nasional (SPN), namun demikian, yangbersangkutan sudah dua tahun yang lalu mengundurkan diri sebagai hakim ad-hoc di Pengadilan Hubungan Industrial yogyakarta. Rekruitmen hakim ad hoc baru belum pernah dilakukan hingga sekarang ini. Oleh karena itu, pada saat ini hanya ada dua hakim ad hoc sebagaimana disebutkan sebelumnya.

Berkaitan dengan proses dan pertimbangan untuk dapat dipilih dan diangkat sebagai hakim ad-hoc pada satu pengadilan hubungan industrial, maka ketentuan sebagaimana yang diatur dalam peraturan perundang-undang menjadi pertimbangan utama dalam memilih calon hakim ad-hoc tersebut. Hal lain yang menjadi pertimbangan adalah loyalitas dan kinerja calon hakim ad-hoc tersebut kepada selama di serikat pekerja.

Dalam praktek, para hakim ad hoc wakil dari pekerja menemui banyak kesulitan berperkara di pengadilan hubungan industrial. Faktor pertama yang menjadi kendala adalah bergantinya peraturan perundang-undangan yang mengatur mengenai perselisihan hubungan industrial dan kurangnya sosialiasi mengenai hal tersebut. Hal kedua yang menjadi kendala bagi para hakim ad hoc adalah berkaitan dengan hukum acara perdata yang digunakan dalam dalam proses pemeriksaan perkara di pengadilan hubungan industrial. Para hakim ad hoc kurang memiliki pengetahuan dan pengalaman dalam proses beracara di pengadilan. Hal ini berkorekasi bahwa para hakim ad hoc ini yang tidak memiliki latar belakang sarjana hukum sehingga sering sekali tidak memahami dan mengerti aturan main di pengadilan hubungan industrial. Pada intinya hukum formil di pengadilan hubungan industrial mempersulit pihak buruh untuk memperjuangkan hakhaknya.

Hal yang berbeda terjadi pada hakim ad hoc wakil dari pengusaha. Salah satu hakim ad hoc wakil dari pengusaha adalah seorang advokat. Latar belakang hakim ini menjadikan yangbersangkutan telah mempunyai pengalaman, kemampuan dan pengetahuan beracara di pengadilan.

Selama ini kecenderungan netralitas hakim ad-hoc dari pihak pengusaha dalam pemeriksaan di pengadilan hubungan industrial masih dapat dijaga. Meskipun para hakim ad hoc tersebut merupakan wakil dari pengusaha akan tetapi dalam pemeriksaan perkara masih menampakan kemandiriannya.

Hambatan-hambatan secara teknis atau administratif yang dapat mempengaruhi fungsi, peran dan tugas hakim ad-hoc di pengadilan hubungan industrial adalah dalam hal sumber daya manusia (human resource). Tidak ada sama sekali sekali hakim ad hoc dari perwakilan pekerja yang memiliki latar belakang sarjana hukum. Bahkan, salah satu hakim ad hoc yang sempat menjadi hakim ad-hoc dari wakil pekerja memliki latar belakang sebagai sarjana teknik, meskipun yangbersangkutan memiliki pengalaman di bidang hukum selama di perusahaan tempat yangbersangkutan bekerja. Oleh karena itu, tidak dapat dipungkiri bahwa setelah menjadi hakim ad-hoc yangbersangkutan mengalami berbagai kendala dan menemui berbagai kesulitan, karena seringkali berbeda pandangan dengan hakim ad-hoc utusan pengusaha.

Sementara itu, pengadilan hubungan industrial memang dapat dikatakan relatif baru keberadaannya, dan karenanya barangkali memang belum dapat sepenuhnya dapat dinilai efektif tidaknya lembaga baru ini. Namun dalam usianya yang belum genap sepuluh tahun ini, sudah ada beberapa persoalan yang muncul di lapangan, yang apabila tidak segera diselesaikan bukan tidak mungkin akan berpengaruh pada efektifitas dan bahkan eksistensi dari lembaga ini sendiri, yang janjinya adalah menawarkan 
mekanisme penyelesaian perselisihan perburuhan secara 'cepat, tepat, adil dan murah'.

Sebagaimana sudah disinggung di muka, hukum acara yang berlaku pada pengadilan hubungan industrial adalah hukum acara perdata yang berlaku pada pengadilan dalam lingkungan peradilan umum, kecuali yang diatur secara khusus dalam UndangUndang Republik Indonesia Nomor 2 Tahun 2004 Tentang Penyelesaian Perselisihan Hubungan Industrial. Dasar hukum prosedur beracara di pengadilan hubungan industrial setidaknya ada empat, yaitu:

1. Het Herziene Indonesisch Reglement (HIR) atau Reglemen Indonesia yang diperbaharui (Stb.1848 No. 16; Stb.1941 No. 44), berlaku untuk daerah Jawa dan Madura.

2. Rechtsreglement Buitengewesten $(\mathrm{RBg})$ atau Reglemen Daerah Seberang (Stb.1927 No. 227), berlaku untuk daerah luar Jawa dan Madura.

3. Undang-undang Republik Indonesia Nomor 2 Tahun 2004 tentang Penyelesaian Perselisihan Hubungan Industrial, dan

4. Keputusan Ketua MA No. KMA/034/SK/ IV/2006 tentang Petunjuk Pelaksanaan Undang-Undang No. 2 Tahun 2004 Tentang Penyelesaian Perselisihan Hubungan Industrial, dan Keputusan Ketua Mahkamah Agung Republik Indonesia Nomor KMA/035/SK/1V/2006 tentang Pedoman Pelaksanaan Administrasi Perkara pada Pengadilan Hubungan Industrial, keduanya diterbitkan tanggal 19 April 2006.

Dalam prakteknya, ada variasi interpretasi dalam konsistensi penerapan hukum acara perdata ini, antara satu pengadilan hubungan industrial dengan pengadilan hubungan industrial lainnya. Bahkan antara satu majelis hakim dengan majelis hakim lainnya dalam satu pengadilan hubungan industrial. Variasi ini biasanya tergantung pada komposisi hakim yang ada, baik hakim karir maupun hakim ad hoc. Hakim karir cenderung taat pada hukum acara perdata sebagaimana terdapat dalam HIR/RBg, sementara hakim ad hoc, khususnya yang dari unsur serikat buruh, kalau itu hanya akan merugikan buruh cenderung tidak masalah untuk melakukan 'penyesuaian'.

Hal tersebut terlihat dari isu yang mungkin sangat sederhana seperti apakah
Kepala Personalia atau HRD (human Resources Development) memang berhak mewakili pihak perusahaan untuk bersidang di pengadilan hubungan industrial. Sebagian hakim pengadilan hubungan industrial secara tegas menolak apabila mereka tidak dapat menunjukkan kartu Advokat, sementara sebagian hakim pengadilan hubungan industrial yang lain dapat menerimanya, dengan alasan 'untuk mempercepat dan mempermudah proses pemeriksaan di pengadilan hubungan industrial, dan dinilai merupakan praktek yang sudah berlangsung dalam hukum perdata.

Untuk hal yang lebih kompleks seperti dapat tidaknya dikenakan dwangsom (uang paksa) dalam putusan pengadilan hubungan industrial, sebagian hakim mengatakan bahwa terhadap putusan pengadilan hubungan industrial tidak dapat dikenakan dwangsom ini karena ada aturan bahwa untuk perkara yang gugatannya meliputi sejumlah uang tidak dapat dikenakan dwangsom.

Sementara itu hakim ad hoc dari unsur serikat buruh cenderung berpendapat bahwa dapat saja dikenakan dwangsom di pengadilan hubungan industrial, karena tidak semua tuntutan dalam kasus perburuhan terkait dengan uang, seperti tuntutan dipekerjakan kembali misalnya dalam kasus pemutusan hubungan kerja sewenangwenang. Dalam penelitian ditemukan bahwa sering perusahaan enggan melaksanakannya kalau tidak dipaksa, dan oleh karena itu maka dwangsom dalam kasus ini diperlukan untuk memaksa pihak perusahaan agar memnuhi isi putusan pengadilan..

Selain itu ada beberapa isu lain lagi, namun yang kiranya menjadi penting di sini adalah pertanyaan apakah hukum acara perdata yang murni memang dapat begitu saja sepenuhnya diterapkan dalam hubungan perburuhan? Sebagaimana sudah sejak awal dibahas. oleh para pendirinya sendiri. Hukum perburuhan memang adalah upaya melampaui dikotomi hukum privat dan hukum publik. Berbeda dengan hukum privat yang memperjualbelikan barang, dalam hubungan perburuhan yang diperjualbelikan adalah kerja (labour) yang tidak dapat dipisahkan dari manusianya (buruh) itu sendiri, dan karenanya harus dibedakan.

Sejak masih dalam bentuk Rancangan Undang-undang, UU Penyelesaian Perselisihan Hubungan Industrial sudah menerima banyak kritik. Kritik tidak hanya 
datang dari serikat buruh dan organisasi nonpemerintah pemerhati buruh, tetapi juga dari kalangan akademisi.

Kritik diberikan mulai dari persoalan kelemahan konseptual undang-undang itu sendiri yang cenderung menjadi pelemparan tanggung jawab negara untuk melindungi buruh oleh eksekutif (kementerian Tenaga Kerja) kepada yudikatif (adalah pengadilan hubungan industrial). Dan cenderung mengarah pada proses penyelesaian perselisihan perburuhan yang tidak akan menguntungkan mayoritas buruh Indonesia, yang memiliki sumber daya lemah untuk menghadapi sebuah proses persidangan di pengadilan dengan segala kompleksitasnya

Kritik juga diarahkan pada kurangnya kejelasan konseptual dari undang-undang itu sendiri, mulai dari konsep perundingan bipartit yang tidak mewajibkan adanya niat baik (good faith) maupun insentif negatif berupa akibatakibat karena gagal dilakukan. Pemisahan perselisihan pemutusan hubungan kerja sebagai kategori terpisah, yang dapat memungkinkan terjadinya ketidakpastian wilayah hukum apakah perselisihan yang timbul akibat pemutusan hubungan kerja adalah perselisihan hak atau perselisihan pemutusan hubungan kerja. Persoalan penting dicermati karena pemutusan hubungan kerja akan memiliki wilayah hukum yang 'pertama dan terakhir' untuk perselisihan hak, tapi tidak atas perselisihan pemutusan hubungan kerja.

Serikat buruh sendiri menilai Undangundang Republik Indonesia Nomor 2 Tahun 2004 dibentuk dengan didasarkan pada beberapa asumsi yang keliru, seperti bahwa sistem peradilan umum sudah bersih dan dapat dipercaya, dan bahwa buruh dan serikat buruh sudah memiliki kemampuan hukum (legal skill) yang cukup untuk berperkara di pengadilan. Hal tersebut pada akhirnya berakibat makin dilemahkannya peran serikat buruh dalam proses penyelesaian perselisihan perburuhan.

Dari penelitian di lapangan terdapat beberapa persoalan yang menjadi hambatan hakim ad hoc pengadilan hubungan industrial dalam menjalankan perannya.

a. Kecenderungan penerapan hukum acara perdata secara 'murni' problematis

Hukum acara perdata pada dasarnya mengandaikan adanya posisi yang 'seimbang' antara para pihak yang bersengketa, dan pengadilan menjadi semacam wasit yang 'netral' yang akan memutus sesuai dengan hukum yang ada. Masalahnya, dalam hubungan perburuhan relasi yang simetris adalah mitos, dan hukum perburuhan pun dikembangkan sebagai sebuah disiplin tersendiri dalam ilmu hukum untuk membongkar mitos ini.

Penerapan hukum acara perdata dalam pengadilan hubungan industrial yang berfungsi memeriksa dan menyelesaikan perselisihan dalam hubungan perburuhan, kalau dilaksanakan secara kaku dan legalitistik-formal malah hanya akan menimbulkan persoalan baru bagi buruh. Penelitian di lapangan menunjukkan bahwa problem utama yang dialami para hakim ad hoc ketika pertama memeriksa berkas gugatan buruh adalah lemahnya kelengkapan prosedural dan standar sebuah gugatan perdata, seperti soal surat kuasa, rumusan gugatan antara posita (fakta hukum) dan petitum (tuntutan hukum) yang tidak sambung, teknik bersidang dan mengajukan pertanyaan dan kelengkapan gugatan seperti bukti, saksi, dan sebagainya.

b. Kekurangan dan ketidakjelasan konseptual Undang-Undang Republik Indonesia Nomor 2 Tahun 2004.

Sebagaimana sudah diuraikan di atas, Undang-undang Republik Indonesia Nomor 2 Tahun 2004 memiliki persoalan terkait dengan kekurangan dan ketidakjelasan konseptual yang melekat di dalam rumusan pasal-pasalnya. Hal paling terlihat adalah pemisahan jenis perselisihan pemutusan hubungan kerja dengan perselisihan hak.

Praktek yang terjadi menunjukkan bahwa seringkali apa yang pada awalnya sebuah perselisihan hak, tiba-tiba beralih menjadi perselisihan pemeutusan hubungan kerja. Pemutusan hubungan kerja memang salah satu upaya paling mudah bisa dilakukan oleh perusahaan untuk mencegah buruhnya memperjuangkan haknya. Pada dasarnya perselisihan hak merupakan perselisihan soal penerapan atau

Interpretasi atas pelaksanaan undang-undang atau seperti perjanjian kerja bersama. Dengan memasukkannya sebagai salah satu dasar perselisihan 
yang sama prosedurnya dengan jenis perselisihan lainnya berakibat pada makin lamanya proses penyelesaian, yang lagi-lagi, akan lebih merugikan buruh dibanding pengusaha.

Undang-undang juga secara 'tanggung' membatasi jenis-jenis perselisihan perburuhan yang masuk dalam wilayah kewenangannya. Setidaknya ada lima jenis perselisihan yang dibiarkan berada di luar jalur hukum untuk penyelesaiannya, yaitu: perselisihan antara serikat buruh dengan anggotanya, perselisihan antara buruh dengan pemerintah, perselisihan antara organisasi pengusaha serta organisasi pengusaha dengan anggotanya, dan perselisihan pemagangan (internship).

c. Persoalan uang tunjangan bagi hakim ad hoc yang kadang terlambat turun, potensial menghambat kinerja hakim ad hoc dan dapat merupakan alasan korupsi pengadilan yang disengaja.

Meski resmi menjalankan keweangannya pada 14 Januari 2006, tetapi pada bulan Mei/Juni 2006 Pengadilan hubungan industrial secara aktual mulai memeriksa perkara. Pada waktu itu surat keputusan presiden tentang pengangkatan sudah keluar, namun surat keputusan mengenai pencairan dana untuk pembayaran honor hakim ad hoc belum juga keluar.

Akibatnya para hakim ad hoc ini pun harus bekerja tanpa upah (atau 'tunjangan', menurut istilah Undangundang Republik Indonesia Nomor 2 Tahun 2004), dan lebih banyak mengandalkan uang tabungan yang dimiliki. Bagi hakim dari unsur pengusaha, yang umumnya memang sudah bekerja dengan upah tinggi, ini barangkali tidak terlalu masalah. Tapi bagi hakim dari serikat buruh maka hal tersebut merupakan masalah yang besar dan sangat serius. Berbeda dengan rekannya hakim ad hoc dari unsur pengusaha, banyak dari hakim ad hoc dari serikat buruh ini sudah berhenti dari pekerjaannya yang lama, dan memilih full-time sebagai hakim ad hoc.

d. Soal imparsialitas dan tantangan struktural hakim ad hoc yang tidak selesai
Tantangan yang dihadapi hakim ad hoc, khususnya yang dari unsur serikat buruh, tidak hanya datang dari pengusaha, tetapi juga dari sesama buruh yang minta agar kasusnya dimenangkan. Padahal hakim ad hoc juga terikat pada prinsip imparsialitas. Begitu menjadi hakim, baju asalnya harus dilepas juga. hakim ad hoc dari unsur buruh ini terlihat lebih khawatir dengan persoalan imparsialitas ini, di satu sisi mereka merasa harus berpihak pada buruh, tetapi pada saat sama juga harus imparsial. Hal sama sepertinya tidak terlalu jadi masalah bagi rekannya hakim ad hoc dari unsur pengusaha, yang sudah mengikuti pembinaan secara resmi dari Apindo (Asosiasi Pengusaha Indonesia) yang mengutusnya.

Uraian di atas menunjukkan meski masih relatif belum lama beroperasi, persoalan-persoalan, baik yang sudah bisa diduga dengan semata membaca rumusan undang-undang maupun yang kemudian ditemukan dalam prakteknya kemudian, rupanya cukup laten dan potensial menghambat kinerja lembaga pengadilan hubungan industrial ini.

Persoalan-persoalan yang ada meliputi baik persoalan internal dari institusi pengadilan hubungan industrial sendiri, seperti kualitas hakim dan kepaniteraan maupun persoalan eksternal pengadilan hubungan industrial seperti kurangnya kemampuan dan aksesibilitas buruh dan serikat buruh untuk menjalani proses dan prosedur beracara di pengadilan hubungan industrial. Semuanya dapat memberi dampak yang signifikan pada kinerja, bahkan eksistensi, dari pengadilan hubungan industrial sendiri. Tanpa adanya penyelesaian terhadap baik masalah eksternal maupun internal ini, pengadilan hubungan industrial bukan akan menjadi solusi bagi persoalan perburuhan di Indonesia, akan tetapi malah menjadi bagian dari masalah itu sendiri. Jika situasi seperti ini tak bisa dihindarkan pihak buruhlah yang akan mengalami kerugian yang paling besar.

\section{d. Simpulan \\ Berdasarkan permasalahan dan hasil penelitian serta pembahasan sebagaimana}


yang telah diuraikan sebelumnya maka dapat disimpulkan bahwa:

1. Salah satu alasan utama dimasukkannya hakim ad hoc dalam satu pengadilan hubungan industrial adalah untuk membantu para hakim karir dalam menganalisis berbagai kasus yang dihadapi. Berdasar hal tersebut diperlukan hakim yang ahli yang disebut juga hakim ad hoc. Alasan lain atas keberadaan hakim ad hoc ini adalah bahwa para hakim karir banyak yang tidak memahami hukum ketenagakerjaan dalam arti luas. Disini, hakim ad hoc diharapkan berperan, terlebih bila hakim ad hoc tersebut berasal dari kalangan professional yang memahami praktek-praktek di lapangan. Hakim ad hoc untuk perkaraperkara di pengadilan dibutuhkan untuk mendapatkan keseimbangan terutama jika ada masalah-masalah yang kompleks yang menyangkut hukum perdata internasional, cyber law dan lain-lain Berbeda dengan hakim ad hoc di pengadilan khusus lainnya, seperti pengadilan niaga dan pengadilan tipikor, hakim ad hoc di pengadilan hubungan industrial berasal dari wakil pengusaha dan wakil serikat pekerja. Oleh karena itu, komposisi majelis hakim pengadilan hubungan insdustrial terdiri dari satu orang hakim karir sebagai ketua majelis dan dua orang hakim ad hoc. Satu hakim ad hoc merupakan wakil dari pengusaha dan yang lainnya adalah wakil dari serikat pekerja. Komposisi tersebut adalah cermin dari upaya mempertahankan model tripartit dalam sistem pengadilan hubungan industrial sebagimana terdapat dalam Panitia penyelesaian perselisihan Perburuhan Daerah/Pusat yang digantikannya

2. Beberapa persoalan yang menjadi hambatan hakim ad hoc pengadilan hubungan industrial dalam menjalankan perannya, yaitu (a) kecenderungan penerapan hukum acara perdata secara 'murni' problematis, (b) kekurangan dan ketidakjelasan konseptual Undang-undang Republik Indonesia Nomor 2 Tahun 2004 tentang Penyelesaian Hubungan Industrial, (c) Persoalan uang tunjangan bagi hakim ad hoc yang kadang terlambat turun, potensial menghambat kinerja hakim ad hoc dan dapat merupakan alasan korupsi pengadilan yang disengaja, (c) soal imparsialitas dan tantangan struktural hakim ad hoc yang tidak selesai

\section{E. Saran}

Berdasarkan kesimpulan penelitian sebagaimana yang telah diuraikan sebelumnya maka perlu disarankan :

1. Perlunya peningkatan pengetahuan hakim karir terhadap hukum ketenagakerjaan dengan cara memberikan pelatihan, mengikutsertakan para hakim karir pengadilan hubungan industrial dalam kegiatan ilmiah yang berkaitan dengan hukum ketenagakerjaan. Bahkan jika diperlukan dikirimkan untuk mengambil studi lanjut di bidang ketenagakerjaan.

2. Untuk mengatasi hambatan yang muncul disarankan untuk (a) menerapkan hukum acara perdata yang dtidak perlu murni problematis, (b) perlunya kejelasan konseptual Undang-Undang Republik Indonesia Nomor 2 Tahun 2004 tentang Penyelesaian Hubungan Industrial, (c) perlunya lebih memperhatikan kembali tunjangan hakim ad hoc agar meningkatkan kinerja hakim ad hoc ini, dan (d) perlunya segera menyelesaikan persoalan imparsialitas dan tantangan struktural hakim ad hoc. 


\section{daftar Pustaka}

Anonim. 2004. Undang-undang Republik Indonesia (UU RI) Nomor 2 Tahun 2004 tentang Penyelesaian Perselisihan Hubungan Industrial (LNRI Tahun 2004 Nomor 6. TLNRI Nomor 4356)

1986. UU RI Nomor 2 Tahun 1986 tentang Peradilan Umum (LNRI 1987 Nomor 20, TLNRI Nomor 3327

. 2004. Keputusan Ketua MA No. KMA/034/SK/IV/2006 tentang Petunjuk Pelaksanaan Undangundang No. 2 tahun 2004 tentang Penyelesaian Perselisihan Hubungan Industrial.

2004. Keputusan Ketua Mahkamah Agung Republik Indonesia Nomor KMA/035/SK/1V/2006 tentang Pedoman Pelaksanaan Administrasi Perkara pada Pengadilan Hubungan Industrial

. 1847. Staatsblad (stb) 1847 Nomor 23 tentang Reglement op de Rechterlijke Organisatie in het Beleid der Justitie Indonesie (RO)

TT. Stb.I848 no. 16; S.I941 no. 44 tentang Het Herziene Indonesisch Reglement (HIR) atau Reglemen Indonesia yang Diperbaharui untuk Jawa dan Madura.

TT. Stb. 1927 no. 227 tentang Rechtsreglement Buitengewesten (RBg) atau Reglemen Daerah Seberang untuk luar Jawa dan Madura.

Ari Hernawan. 2011. "Pengaturan dan Implementasi Mogok Kerja di Indonesia”. Disertasi S-3. Fakultas Hukum Universitas Gadjah Mada. yogyakarta : tidak diterbitkan.

Kumar, Ranjit. 1999. Research Methodology: A Step-by-Step guide for Beginners. Melbourne: Addison Wedley Longman Australia Pty. Limited.

Lalu Husni. 2005. Penyelesaian Perselisihan hubungan Industrial melalui Pengadilan dan di Luar Pengadilan. Jakarta: Raja Grafindo Persada.

Maria SW. Sumardjono. 1989. Pedoman Pembuatan Usulan Penelitian. Jakarta: PT. Gramedia.

Rani Murni Inidyastuti. 2012. Pembentukan Pengadilan hubungan Industrial Yogyakarta. yogyakarta. Wawancara. 18 Mei..

Rani Murni Inidyastuti. 2012. Yuridiksi PhI Yogyakarta. Wawancara. 24 April.

Ronny Hanitijo Soemitro. 1994. Metodologi Penelitian hukum dan Jurimetri. Jakarta : Ghalia Indonesia.

Sudikno Mertokusumo. 2009. hukum Acara Perdata Indonesia. edisi keenam. yogyakarta: Liberty.

Suharsimi Arikunto. 1993. Prosedur Penelitian Suatu Pendekatan Praktek. ed. Revisi II. Jakarta: Rineka Cipta.

Tata Wijayanta. 2007. "Pelaksanaan Pasal 302 ayat (3) UU RI Nomor 37 Tahun 2004 Berkaitan Dengan Pelantikan Hakim Ad Hoc Dalam Perkara Kepailitan." Legality. Fakultas Hukum Universitas Muhamadiyah Malang (UMM). ISSN: 0854-6509 Akreditasi No. 23a/DIKTI/Kep/2004. Vol. 15 No. 1, Maret - Agustus 2007, hlm. 125-139.

2004. "Hakim Ad Hoc Dalam Penyelesaian Perkara Kepailitan di Pengadilan Niaga Jakarta Pusat Setelah Berlakunya Perma RI Nomor 2 Tahun 2000." Laporan akhir Penelitian. Lembaga Penelitian dan Pengabdian Masyarakat (LPPM) Universitas Gadjah Mada (UGM). yogyakarta: Tidak Diterbitkan.

. 2008. "Penyelesaian Kes Kebankrapan di Pengadilan Niaga Indonesia dan Mahkamah Tinggi Malaysia: Suatu Kajian Perbandingan." Tesis Doktor Falsafah Universiti Kebangsaan Malaysia. Bangi: Tidak Diterbitkan. 